\title{
Tüketici Yenilikçiliğinin Akıllı Saat Kullanmaya Devam Etme Niyeti Üzerindeki Etkisinde Hedonik ve Faydacı Değerin Aracı Rolü ${ }^{1}$
}

(Araştırma Makalesi)

The Mediating Role of Hedonic and Utilitarian Value in The Impact of Consumer Innovation on The Intention to Continue Using Smartwatches Doi: 10.29023/alanyaakademik. 870648

\section{Bülent YILDIZ}

Dr. Öğr. Üyesi, Kastamonu Üniversitesi İktisadi ve İdari Bilimler Fakültesi, Işsletme (Türkçe) dr.yildiz.bulent@gmail.com

Orcid No:0000-0002-5368-2805

\section{Dilber Nilay KÜTAHYALI}

Öğr. Gör., Kastamonu Üniversitesi Küre Meslek Yüksekokulu nilaykutahyali@kastamonu.edu.tr

Orcid No: 0000-0003-4673-5179

Bu makaleye atıfta bulunmak için: Yıldız, B. \& Kütahyalı, D. N. (2021). "Tüketici Yenilikçiliğinin Akıllı Saat Kullanmaya Devam Etme Niyeti Üzerindeki Etkisinde Hedonik ve Faydacı Değerin Aracı Rolü", Alanya Akademik Bakış, 5(2), Sayfa No.705-726.

Anahtar kelimeler:

Akıllı saat, tüketici yenilikçiliği, hedonik ve faydacı değer

Makale Geliş Tarihi: 29.01.2021

Kabul Tarihi:

12.04.2021

\section{ÖZET}

Her alanda olduğu gibi teknoloji alanında da yenilik kaçınılmazdır ki yeniliğin belki de en çok yaşandiğı alanların başında gelmektedir. Bu teknolojik değişimden nasibini alan bir sektör de akull saattir. Akull saat kullanım alışkanlığ ise giderek yaygınlaşmaktadır. Bu bağlamda bu çalışmada akıllı saat kullanan tüketicilerin yenilikçilik özelliklerinin akıllı saat kullanımına devam etme niyeti üzerindeki etkisi araştırılmaktadır. Ayrıca bu etkide hedonik ve faydacı değerin aracılık rolü araştırılmıştır. Bu amaçla yapisal eşitlik modeli ve process makro analizleri gerçekleştirilmektedir. Yapılan analizler neticesinde tüketici yenilikçiliğinin hedonik ve faydacı değeri anlaml olarak etkilediği tespit edilmektedir. Hedonik ve faydact değerin de akıllı saat kullanımına devam etme niyetini anlaml olarak etkilediği bulgusuna ulaşllmaktadır. Yapılan aracılık testi sonucunda ise tüketici yenilikçiliğinin akıllı saat kullanımına devam etme niyeti üzerindeki etkisinde hedonik ve faydacı değerin güçlü aracılık etkisi olduğu tespit edilmektedir. Analiz bulguları göstermektedir ki tüketici yenilikçiliğinin kullanım niyeti üzerinde direkt etkisi bulunmamaktadır. Bu niyet güçlü olarak hedonik ve faydacı değer algısı üzerinden gerçekleşmektedir.

\footnotetext{
${ }^{1}$ Bu çalışma için Kastamonu Üniversitesi Sosyal ve Beşeri Bilimler Araştırma ve Yayın Etik Kurulu'nun 25.12.2020 tarih ve 4/11 sayılı kararınca "Etik Kurul Onayı”" alınmıştır.
} 
Keywords:

Smartwatch, consumer innovation, hedonic and utilitarian value

\begin{abstract}
As in every field, innovation is inevitable in the field of technology, which is perhaps one of the areas where innovation is experienced the most. Another sector that has its share of this technological change is the smart watch. Smart watch usage is increasingly common. In this context, in this study, the effect of the innovativeness features of consumers using smart watches on the intention to continue using smart watches was investigated. In addition, the mediating role of hedonic and utilitarian value in this effect has been investigated. For this purpose, structural equation model and process macro analysis were carried out. As a result of the analysis, it has been determined that consumer innovativeness significantly affects hedonic and utilitarian value. It was found that hedonic and utilitarian values also significantly affect the intention to continue using the smart watch. As a result of the mediation test, it was determined that hedonic and utilitarian value have a strong intermediary effect on the effect of consumer innovativeness on the intention to continue using smart watches. Analysis findings show that consumer innovativeness has no direct effect on intention to use. This intention is realized through strong hedonic and utilitarian value perception.
\end{abstract}

\section{GÍRIŞ}

Tüketim kavramının baş aktörü olan tüketici, yenilikleri denemeye istekli ve meraklı yönüyle bilinmektedir. Bu istek yeni düşünceler, oluşumlar, gelişimler ve ilerlemeler üzerinde önemli bir rol oynamaktadır. Bu durum neticesinde tüketicilerin belirli bir ölçüde yenilikçi olduğu kabul edilebilir. Yenilikçilik, hakkını yeni olandan tarafa kullanma olarak ifade edilebilir. Aynı zamanda yenilikçilik, bir bireyin yeni fikirlere açık olma ve başkalarının iletilen deneyimlerinden bağımsız olarak yenilik kararları alma derecesidir (Midgley ve Dowling, 1978: 236). Tüketici yenilikçiliği kavramı da bir bireyin yeni fikirleri benimsemede sosyal sisteminin diğer üyelerine göre nispeten daha erken davranma derecesi olarak tanımlanmaktadır (Leicht vd., 2018: 4).

Tüketici yenilikçiliği, yeni çıkan ürünleri benimsemede erken davranan bir faktörü tanımladığına göre bu tüketicilerin teknolojik ürünlerin gelişim göstermesini de yakından takip ettikleri gerektiği kabul edilebilir. Özellikle teknolojinin giyilebilir bir ürün olarak algılanır hale gelmesini sağlayan akıllı saatlerin popüler hale gelmesinde yenilikçi tüketicilerin elbette ki katkısı bulunmaktadır. Akıllı saat tüketiciler için ilk ticari giyilebilir cihaz olarak kabul edilmektedir (Jung vd., 2016: 899). Akıllı saat, "kısa menzilli kablosuz bağlantı yoluyla diğer cihazlara bağlanabilen, hesaplama gücüne sahip, bileğe takılan bir cihazdır. Uyarı bildirimleri sağlamakta, kişisel verileri bir dizi sensör aracılığıyla toplayıp depolamaktadır (Nascimento vd., 2018: 157). Bu cihazlar bireylere hareket halindeyken gelen mesajlara bakma, bildirimleri okuma ve birtakım dijital verilere erişim kolaylığı sunmaktadır.

Akıllı saat bağlamından yola çıkacak olursak tüketici, tüketim faaliyetini yerine getirirken hedonik değerlere ya da faydacı değerlere göre davranış sergilemektedir. Hedonik değer, alışveriş deneyiminin daha çok fantezi ve duygusal yönlerinden alınan değeri yansıtırken, faydacı değer, alışveriş deneyiminin bilişsel ve duygusal olmayan sonuçlarından alınan değeri yansıtmaktadır. Faydacı bakış açısına göre, tüketiciler, hedeflerine minimum rahatsızlıkla ulaşmak için verimli ve zamanında ürün satın almak isteyebilmekte ve geri kalan zamanlarını 
diğer önemli görevlere harcayabilmektedir. Hedonik bakış açısına göre ise tam tersine, tüketiciler kendilerini alışveriş sürecinde heyecan veya zevkin tadını çıkarma eğiliminde olabilmektedirler (Chung, 2015: 29).

Yenilikler her alanda yaşanmaktadır. Son zamanlarda akıllı saat kullanımı da giderek daha popüler hale gelmektedir. Akademik çalışmalarda da akıllı teknolojinin kullanımına yönelik çalışmalar olmakla birlikte bu konuyla ilgili yapılan çalışmaların azlığı dikkat çekmektedir ve bu nedenle literatürdeki bu boşluğu gidermeye yönelik çalışma gerçekleştirme gereği duyulmuştur. Bununla birlikte akıllı saat kullanımı bağlamında kullanıcıların devamlılık niyetini oluşturmada yenilikçiliğin rolüne ve bu rol üzerinde hedonik ve faydacı değerin etkisine daha az değinildiği gözlemlenmiştir. Bu nedenle araştırmamızın temel amacını sadece kullanıcı ile akıllı saat ürünü arasındaki bağlantıyı incelemek değil, aynı zamanda kullanmaya devam etme niyetinde iki boyutlu yenilikçilik olan hedonik ve faydacı değerin rolünü belirlemek oluşturmaktadır. Bu amaç doğrultusunda gerçekleştirilen çalışma ile tüketicilerin yenilikçiliğinin akıllı saat teknolojisinin kullanımına devam etme niyeti üzerinde hedonik ve faydacı değerin etkilerinin olup olmadığı tespit edilmeye çalışılmıştır.

\section{KURAMSAL ÇERÇEVE}

\subsection{Tüketici Yenilikçiliği}

Yenilik kavramı Türk Dil Kurumu'nda "yeni olma durumu” olarak tanımlanırken, yenilikçi kavramı ise "yenilikten yana olan" olarak belirtilmektedir (TDK, 2020). Xie (2018) yenilikçiliği, "bir bireyin yeni fikirlere ne ölçüde açık olduğu ve başkaları tarafindan iletilen deneyimlerinden bağımsız olarak yeni kararlar alma derecesi" olarak tanımlamaktadır. Bu tanımlardan yola çıkarak tüketici yenilikçiliğgi kavramı ise, tüketicileri gruplandırırken yeni bir ürünü satın almayı tercih eden tüketicileri tanımlamaktadır.

Tüketici yenilikçiliği kavramı, bir bireyin yeni fikirleri benimsemede diğerlerinden görece daha erken olma derecesi olarak tanımlanmaktadır (Chauhan vd., 2019: 326). Diğer bir tanımda tüketici yenilikçiliği, yeni ürün veya hizmetleri nispeten hızlı bir şekilde benimseme eğilimi olarak tanımlanmıştır ve tüketicilerin mevcut ve önceki seçimlerle kalmak yerine yeni veya farklı ürün veya hizmetleri denemeye yatkınlıkları olarak ifade edilmiştir. Buradan yola çıkarak ihtiyaçları için yeni ürün ve hizmetleri kabul etme eğilimi güçlü tüketiciler yenilikçi olarak kabul edilmektedir (Kim vd., 2020: 3). Tüketici yenilikçiliği ayrıca önceki tercihlere veya tüketim kalıplarına bağlı kalmaktan ziyade yeni ve farklı ürünler ya da markalar satın almaya yatkınlık derecesi olarak tanımlanmaktadır (Rašković vd., 2016: 3683). Tüketicinin yenilikçiliği, bir kişinin bir yeniliği benimsemede genel sosyal sistemin diğer üyelerine göre nispeten daha erken olma derecesi açısından da tanımlanmaktadır (Xie, 2018: 237). Kavram insanların diğerlerinden daha önce yeni ürünler tarafından uyarılma ve yenilik aramaya yönelik doğuştan gelen bir yatkınlığı veya bir kişinin diğerinden nispeten kalıcı ve diğerlerinden farklılaştığı bir kişilik özelliği olarak görülmektedir (Persaud ve Schillo, 2017: 133).

Tüketicilerin yenilikçi davranış tutumları, yeni ürün ve hizmetleri benimsemede önemli bir rol oynamaktadır ve bu durum yenilikçi teknolojilerin benimsenmesinin ana belirleyicilerinden biri olarak açıklanmaktadır (Chauhan vd., 2019: 326). Tüketicilerin yeni fikirleri benimseme istekliliği, belirsizliklerle başa çıkma istekliliği ve risk alma yetenekleri yenilikçi olanlarının en önemli özellikleridir (Chauhan vd., 2019: 328). Yüksek derecede yenilikçiliğe sahip 
tüketiciler meraklıdır, yaratıcı buluşlardan zevk alır ve sonuç olarak yeni ürün veya hizmetleri benimseme eğilimindedir (Kim vd., 2020: 2).

Yüksek düzeyde yenilikçiliğe sahip tüketicilerde risk azaltma stratejilerine girme olasılığı daha düşüktür. Aksine cesaretleri veya risk alma eğilimleri, yeni markaları tercih etmelerine neden olmaktadır. Daha düşük tüketici yenilikçiliği seviyesine sahip bireyler, risk seviyesinin düşük olması nedeniyle yeni ürünler söz konusu olduğunda bilinen marka adlarını tercih ederek algılanan riskle başa çıkmaya çalışmaktadırlar (Truong vd., 2017: 87). Sürekli bilgi araması, yenilikçi tüketicilerin yenilik talepleriyle tutarlı olan daha fazla yeni bilgiye erişmesini sağlar. $\mathrm{Bu}$ nedenle, düşük yenilikçilik seviyelerine sahip tüketicilerle karşılaştırıldığında, yüksek düzeyde yenilikçiliğe sahip olanların, algılanan işlevsel risk nedeniyle bilgi aramasını azaltma olasılığı daha düşük olacaktır (Zhang ve Hou, 2017: 245).

Yenilikçi tüketiciler, genellikle daha gençtir, değişime daha açıktır ve nostaljik değildir (Rašković vd., 2016: 3683). Yenilikçi tüketiciler, yeni ürünler hakkında yeni bilgiler ve fikirler edinme konusunda açıktır. Bu nedenle, yeni ürünleri yenilikçi olmayanlara göre daha erken benimsemeleri ve fikir liderleri olmaları muhtemeldir. Bu tüketiciler, ürün bilgilerini potansiyel tüketicilere iletme görevini de üstlenebilmektedir (Xie, 2018: 237). Yenilikçi tüketiciler yeni ürünleri daha erken benimseme eğilimindedirler. Mükemmel bir ürüne sahip olmaktan daha az endişe duyarlar ve yeni ürünlere sahip olmak için bedel ödemeye gönüllüdürler (Persaud ve Schillo, 2017: 133).

Genel olarak yapılmış çalışmalar tüketici yenilikçiliğini dört temel boyut altında ele almışlardır. Bunlar (Hwang vd., 2020: 274):

- İşlevsel olarak motive edilmiş tüketici yenilikçiliği: Bu boyut pratik ve göreve özgü yönler içermektedir. Bu boyuttaki tüketicinin yeni teknolojiye sahip ürünleri satın alırken kolaylık, zaman tasarrufu ve doğruluğu dikkate alması muhtemeldir.

- Hedonik olarak motive edilmiş tüketici yenilikçiliği: Bu boyut göreli bir kavramdır ve duygusal yönlerle ilgilidir. Bu nedenle, belirli bir tüketici yüksek derecede bu boyutun seviyesine sahip olduğunda, yeni bir teknoloji ürününü seçerken daha çok eğlence ve heyecana odaklanma eğilimindedir.

- Bilişsel olarak motive edilmiş tüketici yenilikçiliği: Yüksek derecede bu boyut seviyelerine sahip olan tüketicilerin çeşitli avantaj ve dezavantajlarını göz önünde bulundurduktan sonra yeni bir teknoloji ürününü kullanma olasılığı daha yüksektir. $\mathrm{Bu}$ boyuta göre tüketici yenilikçi bir ürünü kullanırken avantaj ve dezavantajlarını değerlendirmektedir.

- Sosyal olarak motive edilmiş tüketici yenilikçiliği: Bu boyut farklılaşmaya yönelik kendinden iddialı sosyal ihtiyaç tarafından motive edilen tüketici yenilikçiliği anlamına gelmektedir. Tüketiciler yenilikçi ürünleri satın alarak imajlarını iyileştirmek istediklerinden, tüketicinin yenilikçi ürünü satın alması için sosyal olarak motive edilmiş olması gerekmektedir.

\subsection{Akıllı Saat}

Her geçen gün gelişen teknoloji ile birlikte hayatımızda yeni cihazlar yerini almaya başlamıştır. Akıllı saatler, bileklikler, akıllı gözlükler, giyilebilir kameralar ve jetonlar, klipsler ve takılar dâhil olmak üzere giyilebilir cihazlar günlük yaşantımızda ihtiyaç duyulur hale gelmiştir. Ha vd.'ne (2017: 1262) göre bu siralanan akıllı teknolojiler kendi kendine öğrenir ve beklenmedik 
sonuçlar üretebilir. $\mathrm{Bu}$ cihazların öğrenebilme şekli, davranışlarını kullanıcıyla olan etkileşimlerinden nasıl uyarladıklarına bağlıdır. Bu akıllı cihazlardan biri olan akıllı saatler 2010'lardan itibaren, kullanıcılarının aldıkları bildirimleri takip etmenin daha uygun bir yolunu oluşturmalarına yardımcı olabilecek etkili bir şekilde giyilebilir bir bilgisayar olarak tanıtılmıştır. Aslında bilgisayar teknolojileriyle donatılmış kol saatleri kavramı çok DA yeni değildir. Çünkü bu tür cihazlar bilim kurguda da kullanılmaktaydı (Jung vd., 2016: 900). Günümüz akıllı saatlerinin ortaya çıkışı, 2000 yılında piyasaya sürülen IBM Linux Watch olarak kabul edilmektedir (Choi ve Kim, 2016: 778). Giderek popülaritesini artırarak teknoloji pazarında tercih edilen tüketici ürünlerinden biri haline gelmiştir. Özellikle akıllı telefonların gelişim göstermesinden sonra akıllı saatler de popüler cihaz haline dönüşerek en önde gelen moda giyilebilir ürünü olmuştur (Bölen, 2020a: 1). Yaygın bir kullanım ağına sahip olan akıllı saatin insanların günlük yaşamları üzerinde önemli bir etkiye sahip olması beklenmektedir. En son teknolojiyle etkileşimde bulunmaktan hoşlanan insanlar sürecin yakından takipçisi haline gelmişlerdir (Bölen, 2020b: 1).

Piyasaya sürülen ilk giyilebilir nitelikte moda bileşenlerinden biri olan akıllı saat, tüketiciler için en kapsamlı şekilde, temel olarak e-postadan video kaydına kadar çok sayıda işlevi olan, bileğe takılan bir cihaz türü olarak tanımlanabilir (Bölen, 2020a: 2). Akıllı saat, kısa menzilli kablosuz bağlantı yoluyla diğer cihazlara bağlanabilen, hesaplama gücüne sahip, bilekten takılan bir cihazdır ve kişisel verileri bir dizi sensör aracılığıyla toplar ve depolayarak uyarı bildirimleri gerçekleştirir (Wu vd., 2016: 383). Akıllı saat, günümüzdeki birçok akıllı giyilebilir cihaz türünden biridir. Bu cihaz, bir kullanıcının kişisel alanına yerleştirilebilen, giyilebilen, taşınabilen veya vücuda takılabilen bir elektronik bilgi işlem cihazıdır (Choi ve Kim, 2016: 778).

Diğer bir tanıma göre akıllı saatler bileğe takılan, ekranı olan, kablosuz olarak internete tek başına veya akıllı telefon aracılığıyla bağlanarak uygulamaları çalıştırabilen, genellikle suya dayanıklı, uzun süren pil ömrü ve olası hareket etkileşimlerini mümkün kılan sensörleri nedeniyle belirli çalışma koşullarında kullanım kolaylığı sağlayan cihazlardır (Nascimento vd., 2018: 158). Akıllı saatler, kişisel dijital asistanların yanı sıra zaman tutucu işlevlerine sahip bilgisayarlı kol saatlerini ifade etmektedir. Bu akıllı cihazlar, diğer cihazlara veya ağlara bağlı etkileşimli elektronik cihazlar olarak tanımlanmaktadır (Cho vd., 2019: 321). Akıllı saatler gelişen teknolojisiyle birlikte akıllı telefon sahiplerine bildirimde bulunma, navigasyon talimatlarına karşılık verme, telefon görüşmeleri, kısa mesajlaşma ve internet aramaları yapmak için sesli girişlere kolay erişim sağlamaktadır (Perlman vd., 2019: 8).

Günümüzde akıllı saatlerin çoğu mobil uygulamaları çalıştırabilen, aramaları cevaplayabilen ve telefona bakmak zorunda kalmadan mesajları ve bildirimleri okuyabilen mini giyilebilir cihazlar olarak yararlı işlevler sunmaktadır. Dahası, bazı akıllı saatler koşu hızı, kalp atış hızı ve adım sayısı gibi önemli ölçümleri izlemektedir (Bölen, 2020a: 2). Bu ölçümleri izlemesi fitness aktivitelerini ve egzersiz programlarını istedikleri zaman ölçmek için bir dizi sağlık hizmeti tabanlı uygulamayı da kullanan tüketiciler açısından fayda sağlamaktadır (Al-Emran vd., 2020: 2). Akıllı saatlerin mobil işletim sistemini çalıştırarak Bluetooth veya Wi-Fi bağlantısı üzerinden taşınabilir bir medya oynatıc1, FM radyo oynatıcı, ses ve video dosyaları olarak işlev görme özellikleri de bulunmaktadır (Anggraini vd., 2019: 1267).

Akıllı saat akıllı bir bilgi işlem cihazı olarak görülmekle birlikte aynı zamanda temelde bir tür kol saatidir ve genellikle bu açıdan bakıldığında bir moda öğesi olarak kabul edilmektedir. $\mathrm{Bu}$ nedenle, bir akıllı saatin estetik özellikleri, kullanıcının akıllı saatlere 
bağlanması için önemli faktörler olarak düşünülmelidir (Cho vd., 2019: 322). Kol saatleri veya moda aksesuarları olarak akıllı saatler kare, yuvarlak, kavisli gibi çeşitli ekran şekillerine sahiptir. $\mathrm{Bu}$ cihazlar temel olarak günlük ihtiyaçların bilgisayarlarla birleştiği moda özelliklerini içermektedir. Genel olarak bakıldığında bireyler günlük saat tercihlerinde yuvarlak kol saatlerini diğer şekillere tercih etme eğilimindedir. Bunu kuyumcularda ya da saat satışının yapıldığı mağazalarda sergilenen kol saatlerinden anlamak mümkündür. Akıllı saat bağlamında ise bireylerin genel metinsel bilgi ve multimedya takiplerini gerçekleştirdikleri cihazların kare şeklinde olmasından yola çıkarak tercihlerini kare ekranlı akıllı saatlerden yana kullandıkları görülmektedir (Jung vd., 2016: 900).

\subsection{Hedonik ve Faydacı Değer}

Hedonik değere geçmeden hedonizmi tanımlayacak olursak, kendi zevklerine odaklanmak ve her şeyi kendi zevki için yapmak yaşam tarzı olanlar bu şekilde tanımlanmaktadır. Başka bir tanıma göre hedonizm, incinmekten kaçınan ve zevki hedefleyen davranış tarzlarını savunan bir doktrindir (Çavuşoğlu vd., 2020: 4). Hedonik tüketim fanteziler, duygular ve eğlence ile ilgilidir ve bir kişinin ürünlerle olan deneyiminin daha çok duyusal, fantezi ve duygusal yönleriyle ilgili tüketici davranışının yönleri şeklinde tanımlanmaktadır. $\mathrm{Bu}$ tanım, örneğin tatları, sesleri, kokuları, görsel imgeleri, duygu arayışı, duygusal uyarılmayı ve hayal kurmayı içermektedir (Kuikka ve Laukkanen, 2012: 530). Hedonik tüketim, bir müşterinin alışveriş sırasında algıladığı, rahatsızlığı ortadan kaldırarak ve müşterilerin alışveriş faaliyetlerine odaklanmalarına yardımcı olarak daha yüksek değerler üreten algıdır (Atulkar ve Kesari, 2017: 24). Hedonik değer ise, eğlence ve kaçış gibi deneyimsel faydaların ve fedakârlıkların genel bir değerlendirmesi olarak açıklanmaktadır. Buna göre tüketiciler genellikle sadece görevi tamamlamaktan ziyade deneyimin takdir edilmesi için alışveriş yaparlar (Overby ve Lee, 2006: 1161).

Faydacı değer ise, tüketicinin bir ürün veya hizmetin işlevsel faydaları ve sakıncalarına ilişkin genel değerlendirmesi olarak tanımlanabilir. Tüketici faydacı davranışı, göreve yönelik ve rasyonel olarak tanımlanmıştır ve faydacı değer algısının, tüketici talebinin teşvik ettiği belirli bir alışveriş görevinin tamamlanıp tamamlanmadığına göre belirlendiği ileri sürülmektedir (Lee ve Wu, 2017: 2454). Faydacı müşteriler, satın alımları için daha fazla değer elde etme isteğine sahiptirler. Faydacılarda temel kriter ekonomik olarak kazanç olduğundan alışveriş için harcadıkları zamanı, çabayı ve parayı feda etmek istemezler (Kesari ve Atulkar, 2016: 23). Faydacı değer, satın alma üzerinde düşünme gibi (yani, fiili satın alma işleminden önce ürün, hizmet ve fiyat özelliklerinin dikkate alınması), alışverişin göreve özgü kullanımıyla ilgilidir (Overby ve Lee, 2006: 1161). Faydacı bir bakış açısına göre, tüketiciler davranışlarında oldukça görev odaklı ve rasyoneldir (Ozturk vd., 2016: 107).

Hedonik ve faydacı alışveriş değerleri, tüketicilere iki farklı alışveriş koşulunun yönlendirildiğini önermektedir. Hedonik alışveriş değeri, tüketicilerin zevk, eğlence amaçlı tüketim ve yüksek uyaranlara göre değer aramak için alışveriş yapmalarını önerir. Tersine, faydacı alışveriş değeri, tüketicileri daha verimli ve rasyonel olarak görür ve onlar, görevi tamamlamaya odaklanarak alışveriş yaparlar (Vieira vd., 2018: 426). Faydacı değerler doğası gereği ağırlıklı olarak işlevsel, araçsal ve bilişseldir ve bir amaca yönelik bir araçtır. Alternatif olarak, hedonik değerler akıl almaz, deneysel ve duyuşsaldır ve genellikle somut olmayan ürün özellikleriyle ilgilidir (Noble vd., 2005: 1644). Hedonik alışveriş değeri, alışveriş deneyiminin çok duyusal, fantezi ve duygusal yönlerinden alınan değeri yansıtırken, faydacı alışveriş değeri, 
ürünlerin veya bilgilerin edinilmesini verimli bir şekilde yansıtır ve daha görev odaklı, bilişsel ve alışverişin duygusal olmayan sonucu ile ilgilenmektedir (Jones vd., 2006: 974).

Hedonik değer daha deneyimseldir, faydacı değer ise bilgi odaklı bir vurguyu içerir ve tüketim sürecinin kendisini vurgular. Tüketici deneyimleri açısından, bir tüketim deneyiminin hedonik boyutu, bir ürün veya hizmetin benzersizliğini veya tüketicide uyandırdığı duygusal bağlantıyı içerirken, faydacı değer, ürünlerin veya hizmetlerin etkili, göreve özgü ve ekonomik yönleriyle ilişkilendirilir (Lee ve Kim, 2018: 1335). Faydacı değer, tüketicilerin ürün veya hizmet için sahip olabileceği araçsal beklentilerin karşılanmasını içerir ve genellikle zaman, yer ve sahip olma ihtiyaçlarının rasyonel güdüleri ile eşitlenen bir amaca yönelik bir araçtır (Ryu vd., 2010: 419). Faydacı değer, işlevsel faydalar ve fedakârlıklar hakkında genel bir yargı olarak tanımlanırken hedonik değer, alternatif olarak, faydacı değerden daha öznel ve kişiseldir. Hedonik bir bakış açısıyla, tüketiciler bir ürün veya hizmetin kullanımından eğlence ve şakacılık gibi zevkler elde etmeye çalışırlar. Hedonik bir değer perspektifinden, tüketiciler eğlenceyi arzular ve satın alma sürecini, işlemi tamamlamanın gerekli olmadığı keyifli bir deneyim olarak görür (Ozturk vd., 2016: 107).

\section{LITERATÜR TARAMASI VE HIPOTEZLERIN KURULMASI}

Chae'ya (2009) göre akıllı giyim, elektronik teknolojisinin birleştiği, yeni teknolojiye yönelik tüketici teknolojisi yeniliğinin kabul üzerinde etki yaratacağı yenilikçi bir giysidir. Mani ve Chouk'a (2007) göre de akıllı ürünler, kendilerini diğer mevcut ürünlerden ayıran teknik seçeneklerle donatılmış yeni ürünlerdir. Dolayısıyla tüketiciler bu ürünleri teknolojik yenilikler olarak algılamakta ve yenilikçi olmayan tüketiciler bunlara direnme eğiliminde olabilmektedir. Buradan hareketle de akıllı ürünlerin kullanımında tüketici yenilikçiliğinin önemli bir yere sahip olduğu söylenebilmektedir. Benzer şekilde Zhang vd. (2020) daha yüksek derecede tüketici yenilikçiliğine sahip kişilerin bilgiye erişmeyi daha çok bekleyeceği ve bu nedenle, bu tüketici yenilikçiliğinin tüketicilerin algılanan ürün yenilikçiliğini ve yenilikçi ürünlere ödeme yapma istekliliğini olumlu yönde etkileyebileceğini belirtmektedirler. Yaptıkları araştırmada da bu iddialarını desteklemektedirler. Ju ve Lee (2020) akıllı ürünler üzerinde yaptıkları nitel araştırmada yenilikçi ürünlerin ancak teknolojiye hevesli bir grup yenilikçinin olması durumunda başarılı olabileceği sonucuna varmışlardır. Nikou'nun (2019) Finlandiya'da 156 katılımcı ile gerçekleştirilen akıllı ev teknolojilerinin kullanımında tüketici yenilikçiliğinin etkisinin ölçüldüğü çalışmada tüketicinin algıladığı yenilikçiliğin akıllı teknolojiyi kullanma niyetinde devamlılığa yol açtığı belirlenmiştir. Akıllı ev teknolojisi bağlamında, daha yüksek derecede algılanan yenilikçiliğe sahip bireyin teknolojiyi benimseme niyeti daha yüksek olmaktadır. Krey vd. (2019) tarafından Malezya Üniversitesi'nde akıllı saat kullanıcısı olmayan 999 katılımcı ile gerçekleştirilen çalışmada yenilikçiliği yüksek olan katılımcıların akıllı saatlerde yeni teknolojiyi kullanmak için daha yüksek eğilim gösterdiği sonucuna ulaşılmıştır. Bu bağlamda aşağıdaki hipotez kurulmuştur.

\section{H1: Tüketici yenilikçiliği, akıllı saat kullanmaya devam etme niyetini anlamlı olarak etkiler.}

Noh vd.'ne (2014) göre yenilikçilik gibi tüketici eğilimleri, yeni bir ürünün kabulünü veya reddedilmesini etkilemekte ve yenilikçilik ile hedonik ve faydacı değerler arasındaki ilişki, yeni ürünlerin hedonik veya faydacı değerlere odaklanıp odaklanmayacağını belirlemektedir. Ve yaptıkları araştırma sonucunda yenilikçi genç tüketicilerin, yenilikçi olmayan genç tüketicilere göre havalı giysilere karşı daha güçlü bir hedonik tutuma sahip olacağı sonucuna varmışlardır. Ashraf vd. (2019) da tüketicilerin konsept yeniliği, teknoloji yeniliği ve göreceli avantaj gibi 
çeşitli ürün algılarının, hedonik ve faydacı değerlerini etkilediğini belirtmektedirler. Firmansyah (2016) tarafından Endonezyalı 153 katılımeı ile çalışma gerçekleştirilmiştir. Çalışmada hedonik değer temelli tüketicinin yenilikçilik motivasyonun daha yüksek olacağı iddia edilmektedir. Hedonik olarak güdülenmiş tüketicinin yenilikçilik eğilimin daha yüksek olacağı, ödeme de sunulan herhangi bir ödülün duygusal, hazsal olarak tüketiciyi etkileyeceği düşünülmektedir. Kim'in (2008) Greensboro'daki Kuzey Karolina Üniversitesi'nde lisans öğrencilerinden 196 tanesi ile çalışma gerçekleştirilmiştir. Çalışma sonucunda tüketici yenilikçiliğinin hedonik ve faydacı değeri etkileyip etkilemediğine yönelik hipotezler de test edilmiştir. Analizler neticesinde tüketici yenilikçiliğinin hedonik ve faydacı değer üzerinde doğrudan etkileri olduğu tespit edilmiştir. Noh vd. (2014) tarafından Büyük Amerikan Üniversitesi'nde 265 katılımcı ile çalışma gerçekleştirilmiştir. Çalışma analizi neticesinde gençlerin yenilikçiliğinin hem hedonik (tüketimi eğlenceli yönleri ile algılayanlar) hem de faydacı (tüketimi problem çözme ve görevi yerine getirme olarak algılayanlar) tüketim alışkanlığını pozitif yönlü etkilediği bulunmuştur. Hong vd. (2017) 276 akıllı saat kullanıcısı üzerinde yaptıkları araştırmada tüketici yenilikçiliğinin hedonik ve faydacı değeri anlamlı olarak etkilediği bulgusuna ulaşmışlardır.

Bu bağlamda aşağıdaki hipotezler kurulmuştur.

\section{H2: Tüketici yenilikçiliği hedonik değeri anlamll olarak etkiler.}

\section{H3: Tüketici yenilikçiliği faydacı değeri anlamlı olarak etkiler.}

Ashraf vd. (2019) pazarlama araştırmasının tüketicilerin satın alma kararlarını etkileyen temel özellikleri arasında faydacı ve hedonik değerlerin olduğunu belirtmişlerdir. Yazarlar yaptıkları araştırma sonucunda da hedonik ve faydacı değerin kullanıma devam etme niyetini anlamlı olarak etkilediğini tespit etmişlerdir. Hong vd. (2017) akıllı saatlerin, kullanıcılara kullanmaya veya satın almaya devam etmede önemli roller oynayan hedonik ve faydacı odaklı işlevler sunduğunu belirtmişler ve Tayvan'da 286 akıllı saat kullanıcısı üzerinde çalışma gerçekleştirmiştir. Çalışma bulgularında hedonik değer ve faydacı değerin akıllı saat kullanma sürekliliğini önemli ölçüde etkilediği görülmektedir. Akıllı saat kullanmadaki davranışsal niyet hem duygusal, hazsal değer (hedonik) hem de faydacı değer ile bağlantılı olarak tespit edilmiştir. Zheng vd. (2019) hedonik değerin, alışveriş davranışının eğlenceli ve keyifli yönlerine odaklandığını ve tüketicilerin dürtüsel satın alma davranışını olumlu yönde etkilediğini belirtmişler ve yaptıkları araştırmada hedonik dürtünün direkt olarak satın alma davranışını etkilediğini ancak faydacı dürtünün ise hedonik dürtü vasıtasıyla satın alma davranışını etkilediğini tespit etmişlerdir. Hwang vd. (2020) tarafından Güney Kore'de 427 kişiden oluşan robotik restoran tüketicilerine yönelik araştırma gerçekleştirilmiştir. Araştırma neticesinde tüketicilerin robotik bir restorandan hizmet alma sonucunda keyif duygusunun ön planda olduğu sonucuna ulaşılmıştır. Hedonik değer (duyguya, haza önem veren) temelli tüketicinin yeni teknolojiyi benimseme oranı oldukça yüksek değerde algılanmıştır. Kim (2008) çalışmasında teknolojik olarak yenilikleri takip etmenin ürünü kullanmadaki hedonik ve faydacı tutumların üzerinde etkili olacağını düşünerek gerçekleştirmiş oldukları analizler neticesinde teknolojik yeniliğin hem faydacı hem de hedonik tutumlar üzerinde etkili olduğunu tespit etmişlerdir. Özellikle hedonik değerin yeni bir teknolojiyi benimsemedeki derecesi daha yüksek düzeyde bulunmuştur. Amorim (2017) tarafindan 103 Portekizli katılımcı tarafından Airpod satın alma niyetini ölçmeye yönelik çalışma gerçekleştirilmiştir. Çalışma ile tüketicilerin hedonik değerli tutumlarının faydacı tutumlarına göre daha yüksek olması iddia edilmektedir. Köroğlu ve Yıldız (2019) 406 kişi üzerinde yaptıkları araştırmada hedonik ve 
faydacı tüketimin satın alma davranışını anlamlı olarak etkilediği bulgusuna ulaşmışlardır. Güven (2018) cep telefonları üzerinde yaptığı araştırmada tüketicilerin hedonik ve faydacı değer algılarının kullanım niyetlerini anlamlı olarak etkilediğini tespit etmiştir.

Daha önce yapılan açıklamalarda da tüketici yenilikçiliğinin akıllı ürün kullanımı ile hedonik ve faydacı değer algısı üzerinde etkili olduğu açıklanmıştır. Bu doğrultuda tüketicilerin yenilikçi özelliklerinin tek başına kullanma niyetinde etkili olmayacağı, yenilikçiliğin hedonik ve faydacı değer algısını etkilemesi neticesinde de kullanma niyetinin meydana geleceği yazarlar tarafindan düşünülmektedir.

$\mathrm{Bu}$ bağlamda aşağıdaki hipotezler kurulmuştur.

H4: Hedonik değer, akıllı saat kullanmaya devam etme niyetini anlamlı olarak etkiler.

H5: Faydacı değer, akıllı saat kullanmaya devam etme niyetini anlamlı olarak etkiler.

H6: Tüketici yenilikçiliğinin akıllı saat kullanmaya devam etme niyeti üzerindeki etkisinde hedonik değerin aracı rolü vardır.

H7: Tüketici yenilikçiliğinin akallı saat kullanmaya devam etme niyeti üzerindeki etkisinde faydacı değerin aracı rolü vardır.

\section{YÖNTEM VE BULGULAR}

Çalışmanın temel amacını tüketici yenilikçiliği kapsamında akıllı saat kullanımına devam etme niyeti üzerinde tüketim alışkanlıkları olarak ikiye ayrılan hedonik ve faydacı değerin etkisini belirlemek oluşturmaktadır. Ayrıca tüketici yenilikçiliğinin akıllı saat kullanmaya devam etme niyeti üzerindeki etkisinde hedonik ve faydacı değerlerin rolünün olup olmadığını belirlemekte diğer amaçlarıdır.

Araştırmanın kapsamını 2020 Aralık ayı ve 2021 Ocak ayında Ankara ilinde ikamet etmekte olup online olarak hazırlamış olduğumuz ankete katılım sağlayan 122 akıllı saat kullanıcıları oluşturmaktadır. Ankara ilinde akıllı saat kullanıcılarının sayısının tespit edilmesinin mümkün olmaması nedeniyle araştırmanın evreni net olarak belirlenememektedir. Ankara iline özel olarak akıllı saat satış rakamları verilerine de ulaşılamamaktadır. İçinde bulunduğumuz sağlık koşullarının elverişsizliği ve kısıtlamalar nedeni ile online anket yöntemi tercih edilmiştir ve bu durumda çalışmanın en büyük kısıtı olarak görülmektedir. Bu nedenle çalışmada kartopu örneklemi kullanılmıştır. Bir akıllı saat kullanıcısına ulaşıldıktan sonra akıllı saat kullanan başka bir tanıdığı olup olmadığı sorulmuştur. Bu şekilde örneklem çoğaltılmaya çalışılmıştır. $\mathrm{Bu}$ nedenle araştırmanın evreninin kaç kişiden oluştuğu net olarak bilinememektedir.

Bu çalışma için Kastamonu Üniversitesi Sosyal ve Beşeri Bilimler Araştırma ve Yayın Etik Kurulu’nun 25.12.2020 tarih ve 4/11 sayılı kararınca “Etik Kurul Onayı” alınmıştır.

Araştırma kapsamında kullanılan ölçekler Hong vd.'nin (2017) çalışmasından alınmıştır. Hong vd. (2017) ölçekler için doğrulayıcı faktör analizi yapmışlar ve kabul edilebilir uyum iyiliği kriterlerini sağlamışlardır. AVE değerini 0.50'nin ve CR değerini de 0.70'in üzerinde elde etmişlerdir. Güvenilirlik analizi sonucunda alfa katsayısı değerini tüketici yenilikçiliği ölçeği için 0.851 , hedonik değer için 0.820 , faydacı değer için 0.855 ve kullanıma devam etme niyeti ölçeği için 0.917 olarak elde etmişlerdir. Anket formu iki bölümden oluşmaktadır. İlk bölümde katılımcıların demografik bilgilerini öğrenmeye yönelik sorular yer almaktadır. İkinci bölümde ise tüketici yenilikçiliği, hedonik değer, faydacı değer ve akıllı saat kullanma niyetine devam 
üzerine oluşturulan likert tipi ifadeler yer almaktadır. Anket 5'li Likert tipi (1-Kesinlikle Katılmıyorum, ..., 5-Kesinlikle Katıliyorum) olarak oluşturulmuştur.

Araştırmanın modeli Şekil 1'de verilmiştir.

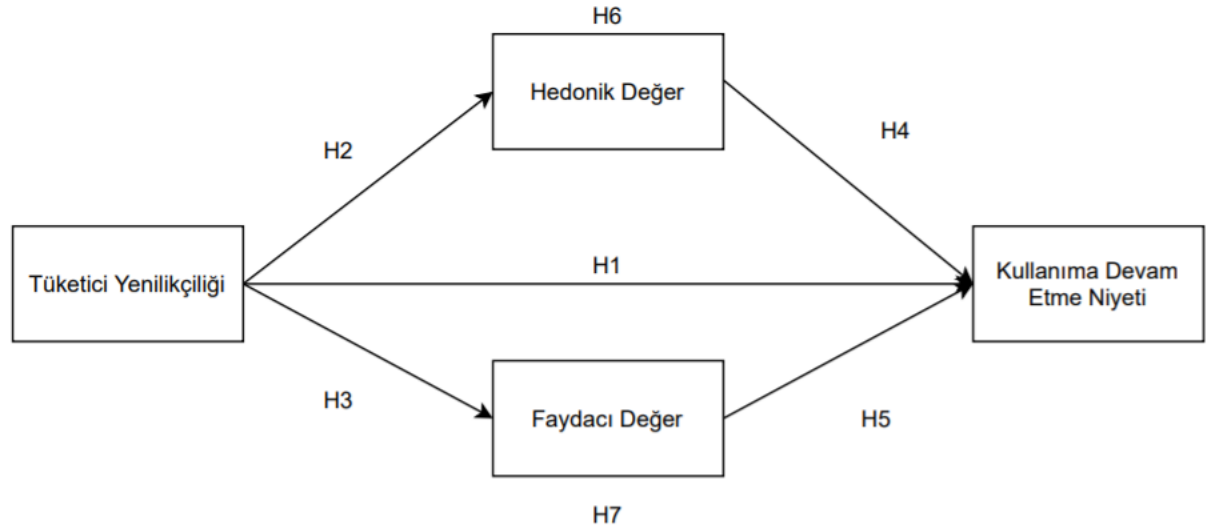

Şekil 1. Araştırmanın Modeli

Bulgular kısmında öncelikli olarak araştırmaya katılanların bazı demografik bulgularına yer verilmiştir. Bu bulgular Tablo 1'de verilmiştir.

Tablo 1. Demografik Bulgular

\begin{tabular}{|l|c|c|}
\hline Cinsiyet & Frekans & Yüzde \\
\hline Kadın & 52 & 42.6 \\
\hline Erkek & 70 & 57.4 \\
\hline Yaş & Frekans & Yüzde \\
\hline $18-25$ yaş arası & 59 & 48.4 \\
\hline $26-35$ yaş aras1 & 34 & 27.9 \\
\hline $36-45$ yaş arası & 21 & 17.2 \\
\hline $46-55$ yaş arası & 6 & 4.9 \\
\hline 56 yaş ve üzeri & 2 & 1.6 \\
\hline Eğitim & Frekans & Yüzde \\
\hline İlköğretim & 15 & 12.3 \\
\hline Lise & 9 & 7.4 \\
\hline Önlisans & 6 & 4.9 \\
\hline Lisans & 64 & 52.5 \\
\hline Lisansüstü & 28 & 23.0 \\
\hline Meslek & Frekans & Yüzde \\
\hline Kamu ve özel sektör işçi / memur & 21 & 17.2 \\
\hline
\end{tabular}




\begin{tabular}{|l|c|c|} 
Kamu ve özel sektör yönetici & 15 & 12.3 \\
\hline Serbest meslek (avukat, doktor, muhasebeci vb.) & 5 & 4.1 \\
\hline Esnaf / Firma sahibi & 6 & 4.9 \\
\hline Unvanlı personel (uzman, müfettiş, öğretmen vb.) & 12 & 9.8 \\
\hline Emekli & 2 & 1.6 \\
\hline Çalışmıyor & 2 & 1.6 \\
\hline Öğrenci & 56 & 45.9 \\
\hline Ev hanımı & 3 & 2.5 \\
\hline
\end{tabular}

Tablo 1'de verildiği üzere katılımcıların 70'i erkek ve 52'si kadındır. 59'u 18-25 arasında, 34'ü 26-35 arasında, 21'i 36-45 arasında, 6'sı 46-55 arasında ve 2'si de 56'nın üzerinde yaşa sahiptir. Katılımcıların çoğunlukla gençlerde oluştuğu görülmektedir. Katılımcıların 64'ü lisans, 28'i lisansüstü, 15'i ilköğretim, 9'u lise ve 6'sı ön lisans seviyesinde eğitime sahiptir. Katılımc1ların çoğunun eğitim seviyesinin yüksek olduğu görülmektedir. Katılımcıların 56'sı öğrencidir. 21'i işçi /memur, 15'i yönetici, 12'si unvanlı personel, 6'sı tüccar, 5'i serbest meslek erbabı olarak çalışmakta olup 3'ü ev hanımı ve 2'si emeklidir ve 2'si de çalışmamaktadır.

Araştırma kapsamında öncelikle araştırmada kullanılan ölçeklerin yapı geçerliği ve güvenilirliği test edilmiştir. Bunun için keşfedici ve doğrulayıcı faktör analizleri ile güvenilirlik analizi ve normal dağılım testleri yapılmıştır. Bu testler SPSS 23 paket programı ile gerçekleştirilmiştir. Tüketici yenilikçiliği ölçeğinin keşfedici faktör analizi bulguları Tablo 2'de verilmiştir.

Tablo 2. Tüketici Yenilikçiliği Ölçeği Faktör Yükleri ve Tanımlayıcı İstatistik

\begin{tabular}{|l|r|r|r|r|r|}
\hline Maddeler & $\begin{array}{c}\text { Faktör } \\
\text { Yükü }\end{array}$ & Çarpıklık & Basıklık & \multicolumn{1}{c|}{ Ort. } & $\begin{array}{c}\text { Std. } \\
\text { Sapma }\end{array}$ \\
\hline $\begin{array}{l}\text { T1: Henüz duymamış olsam bile yeni bir } \\
\text { ürün satın alacağım. }\end{array}$ & .681 & .586 & -.785 & 2.29 & 1.295 \\
\hline $\begin{array}{l}\text { T2: Arkadaş çevremde yeni bir ürün satın } \\
\text { alan ilk kişilerden biriyim. }\end{array}$ & .773 & -.146 & -1.391 & 3.07 & 1.476 \\
\hline $\begin{array}{l}\text { T3: Yeni ürünler hakkında diğerlerinden } \\
\text { daha çok şey biliyorum. }\end{array}$ & .831 & -.314 & -1.054 & 3.25 & 1.370 \\
\hline $\begin{array}{l}\text { T4: Mağazada yeni bir ürün bulunduğunu } \\
\text { duyduğumda satın alacak kadar ilgi } \\
\text { duyacağım. }\end{array}$ & .780 & .064 & -.927 & 2.88 & 1.276 \\
\hline KMO: .739 Ki Kare: 123.977 sd.:6 sig.:.000 Top. Açk. Varyans: \%58.978 & \multicolumn{2}{|l}{} \\
\hline
\end{tabular}

Keşfedici faktör analizi sonucu ölçeğin faktör yükleri 0.681 ile 0.831 arasında elde edilmiştir. KMO değeri 0.739 olarak bulunmuş ve Barlett küresellik testi anlamlı olarak elde edilmiştir. $\mathrm{Bu}$ bulgu da örneklem büyüklüğünün faktör analizi için yeterli olduğu anlamına gelmektedir. Ölçeğin toplam varyansın \%58.978'ini açıkladığı bulgusuna da ulaşılmıştır. Ayrıca ölçek verilerinin normal dağılıma sahip olup olmadığını test edebilmek için çarpıklık ve basıklık değerlerine bakılmıştır. Bu değerlerin -2 ile +2 arasında olduğu tespit edildiğinden dolayı ölçek normal dağılıma sahiptir (Lin vd., 2016).

Hedonik Değer ölçeğinin keşfedici faktör analizi bulguları Tablo 3 'te verilmiştir.

Tablo 3. Hedonik Değer Ölçeği Faktör Yükleri ve Tanımlayıcı İstatistik 


\begin{tabular}{|l|r|r|r|r|r|}
\hline Maddeler & $\begin{array}{c}\text { Faktör } \\
\text { Yükü }\end{array}$ & Çarpıklık & Basıklık & Ort. & $\begin{array}{c}\text { Std. } \\
\text { Sapma }\end{array}$ \\
\hline $\begin{array}{l}\text { H1: Akı1lı saat kullanmak bana eğlenceli } \\
\text { geliyor. }\end{array}$ & .937 & -.684 & -.730 & 3.70 & 1.346 \\
\hline H2: Akı1lı saat kullanmak beni mutlu ediyor. & .919 & -.395 & -1.266 & 3.40 & 1.481 \\
\hline H3: Akıllı saat kullanmak bana keyif veriyor. & .947 & -.586 & -.894 & 3.61 & 1.364 \\
\hline $\begin{array}{l}\text { H4: Akıllı saat kullanmak merakımı } \\
\text { canlandırıor. }\end{array}$ & .887 & -.553 & -.704 & 3.47 & 1.287 \\
\hline KMO: .857 Ki Kare: 451.011sd.:6 sig.:.000 Top. Açk. Varyans: \%85.125 \\
\hline
\end{tabular}

Hedonik değer ölçeğinin faktör yükleri 0.887 ile 0.947 arasında elde edilmiştir. Ölçeğin toplam varyansın \%85.125'ini açıkladığı ve normal dağılıma sahip olduğu, aynı zamanda örneklem büyüklüğünün faktör analizi için uygun olduğu bulgularına ulaşılmıştır.

Faydacı Değer ölçeğinin keşfedici faktör analizi bulguları Tablo 4 'te verilmiştir.

Tablo 4. Faydacı Değer Ölçeği Faktör Yükleri ve Tanımlayıcı İstatistik

\begin{tabular}{|l|r|r|r|r|r|}
\hline Maddeler & $\begin{array}{c}\text { Faktör } \\
\text { Yükü }\end{array}$ & Çarpıklık & Basıklık & Ort. & $\begin{array}{c}\text { Std. } \\
\text { Sapma }\end{array}$ \\
\hline $\begin{array}{l}\text { F1: Akıllı saat kullanmak aramaları ve } \\
\text { mesajları hemen cevaplamamı sağlıyor. }\end{array}$ & .838 & -.670 & -.882 & 3.69 & 1.379 \\
\hline $\begin{array}{l}\text { F2: Akıllı saat kullanmak sağlıklı rutinlerimi } \\
\text { harekete geçirir. }\end{array}$ & .861 & -.444 & -.969 & 3.57 & 1.330 \\
\hline $\begin{array}{l}\text { F3: Akıllı saat kullanmak en yeni bilgileri } \\
\text { almamı sağlıyor. }\end{array}$ & .893 & -.190 & -.914 & 3.21 & 1.274 \\
\hline $\begin{array}{l}\text { F4: Ak1llı saat kullanmak günlük aktiviteleri } \\
\text { takip etmemi sağlıor. }\end{array}$ & .891 & -.581 & -.918 & 3.69 & 1.305 \\
\hline KMO: .783 Ki Kare: 293.341 sd.:6 sig.:.000 Top. Açk. Varyans: \%75.899 \\
\hline
\end{tabular}

Faydacı değer ölçeğinin faktör yükleri 0.838 ile 0.893 arasında elde edilmiştir. Ölçeğin toplam varyansın \%75.899'unu açıkladığı ve normal dağılıma sahip olduğu, aynı zamanda örneklem büyüklügüüün faktör analizi için uygun olduğu bulgularına ulaşılmıştır.

Akıllı Saat Kullanmaya Devam Etme Niyeti ölçeğinin keşfedici faktör analizi bulguları Tablo 5 'te verilmiştir.

Tablo 5. Kullanıma Devam Niyeti Faktör Yükleri ve Tanımlayıcı İstatistik

\begin{tabular}{|l|r|r|r|r|r|}
\hline Maddeler & $\begin{array}{c}\text { Faktör } \\
\text { Yükü }\end{array}$ & Çarpıklık & Basıklık & Ort. & $\begin{array}{c}\text { Std. } \\
\text { Sapma }\end{array}$ \\
\hline $\begin{array}{l}\text { A1: Gelecekte akıllı saati sık sık } \\
\text { kullanacağım. }\end{array}$ & .924 & -.709 & -.638 & 3.77 & 1.310 \\
\hline $\begin{array}{l}\text { A2: Başkalarına akıllı saat kullanmasını } \\
\text { şiddetle tavsiye ederim. }\end{array}$ & .926 & -.632 & -.726 & 3.61 & 1.345 \\
\hline $\begin{array}{l}\text { A3: Gelecekte yeni nesil akı1lı saat satın } \\
\text { almaya devam etmek niyetindeyim. }\end{array}$ & .936 & -.492 & -.918 & 3.57 & 1.336 \\
\hline $\begin{array}{l}\text { A4: Kullanımından vazgeçmek yerine akıllı } \\
\text { saat kullanmaya devam etmek istiyorum. }\end{array}$ & .936 & -.769 & -.490 & 3.75 & 1.300 \\
\hline
\end{tabular}


KMO: .872 Ki Kare: 468.440 sd.:6 sig.:.000 Top. Açk. Varyans: \%86.595

Kullanıma devam ölçeğinin faktör yükleri 0.924 ile 0.936 arasında elde edilmiştir. Ölçeğin toplam varyansın \%86.595'ini açıkladığı ve normal dağılıma sahip olduğu, aynı zamanda örneklem büyüklüğünün faktör analizi için uygun olduğu bulgularına ulaşılmıştır.

Keşfedici faktör analizi ve normallik testinden sonra ölçekler için doğrulayıcı faktör analizi yapılmıştır. Doğrulayıcı faktör analizi AMOS 23 paket programı ile gerçekleştirilmiştir. Doğrulayıcı faktör analizi sonucu elde edilen uyum iyiliği değerleri Tablo 6'da verilmiştir.

Tablo 6. Ölçekler Uyum İyiliği Değerleri

\begin{tabular}{|c|c|c|c|c|c|c|c|c|}
\hline Değişken & $\chi^{2}$ & df & $\chi^{2} / \mathrm{df}$ & GFI & CFI & NFI & SRMR & RMSEA \\
\hline Kriter & & & $\leq 5$ & $\geq .90$ & $\geq .90$ & $\geq .90$ & $\leq .08$ & $\leq .08$ \\
\hline Tüketici Yenilikçiliği & 4.179 & 2 & 2.09 & 0.983 & 0.982 & 0.967 & 0.033 & 0.095 \\
\hline Hedonik Değer & 2.895 & 2 & 1.447 & 0.989 & 0.998 & 0.994 & 0.0105 & 0.061 \\
\hline Faydacı Değer & 0.212 & 2 & 0.106 & 0.999 & 1 & 0.999 & 0.0052 & 0.000 \\
\hline Devam Niyeti & 0.7 & 2 & 0.35 & 0.997 & 1 & 0.999 & 0.0043 & 0.000 \\
\hline
\end{tabular}

Örneklem sayısı $<250$ olduğundan dolayı SRMR değeri de hesaplanmıştır. Küçük örneklemde RMSEA değeri yerine SRMR değerinin dikkate alınması gerektiği belirtilmektedir. Bu nedenle doğrulayıcı faktör analizi neticesinde ölçeklerin kabul edilebilir uyum iyiliği kriterlerini sağlamış olduğu bulgusuna ulaşılmıştır (Yang vd., 2004). Ölçekler için ayrıca güvenilirlik analizi yapılmış ve ortalama açıklanan varyans (AVE) değeri ile bileşen güvenilirliği (CR) değerleri hesaplanarak geçerlik ve güvenilirlik durumu incelenmiştir. Bulgular Tablo 7'de verilmiştir.

Tablo 7. Geçerlik ve Güvenilirlik

\begin{tabular}{|l|r|r|r|}
\hline Değişken & AVE & CR & Alfa Katsayısı \\
\hline Tüketici Yenilikçiliği & 0.46 & 0.769 & .766 \\
\hline Hedonik Değer & 0.805 & 0.942 & .941 \\
\hline Faydacı Değer & 0.68 & 0.894 & .893 \\
\hline Devam Niyeti & 0.82 & 0.948 & .948 \\
\hline
\end{tabular}

Güvenilirlik analizi sonucu alfa katsayısı değerleri $>0.70$ olarak elde edilmiştir. Bu bulgu ölçeklerin güvenilir olduğunu göstermektedir. Ayrıca $\mathrm{CR}>\mathrm{AVE}$ ve $\mathrm{CR}>0.70$ olarak bulunmuştur. AVE değerleri ise tüketici yenilikçiliği ölçeği hariç $>0.50$ olarak bulunmuştur. Tüketici yenilikçiliği ölçeği için bulunan AVE değeri de 0.50 'ye çok yakın bir değerdir ve kabul edilebilir niteliktedir. Bu bulgular ölçeklerin bileşen geçerliği ve güvenilirliğini de saplamakta olduğunu göstermektedir (Kautish ve Sharma, 2019).

$\mathrm{Bu}$ aşamadan sonra araştırma hipotezlerini test edebilmek için öncelikli olarak yapısal eşitlik modeli analizi yapılmıştır. Yapısal eşitlik modelinin analizi AMOS 23 paket programı yardımıyla yapılmıştır. Analiz edilen model Şekil 2'de verilmiştir. 


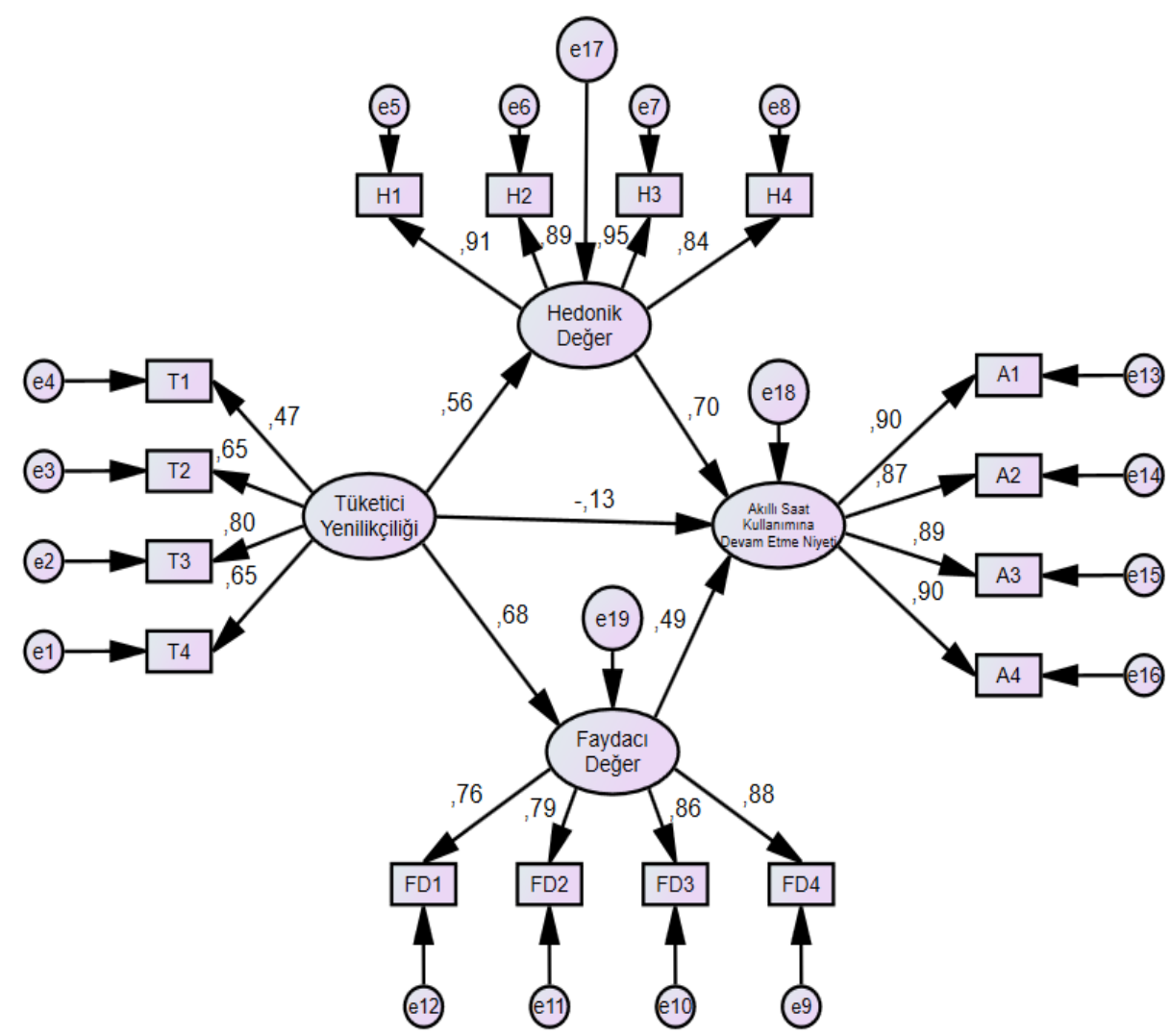

Şekil 2. Yapısal Eşitlik Modeli

Modeli uyum iyiliği değerleri ise Tablo 8'de verilmiştir.

Tablo 8. Model Uyum İyiliği Değerleri

\begin{tabular}{|l|r|r|r|r|r|r|r|r|}
\hline Model & \multicolumn{1}{|c|}{$\boldsymbol{\chi}^{\mathbf{2}}$} & \multicolumn{1}{c|}{ df } & \multicolumn{1}{|c|}{$\boldsymbol{\chi}^{\mathbf{2} / \mathbf{d f}}$} & \multicolumn{1}{l|}{ GFI } & \multicolumn{1}{c|}{ CFI } & \multicolumn{1}{l|}{ NFI } & \multicolumn{1}{c|}{ SRMR } & \multicolumn{1}{l|}{ RMSEA } \\
\hline Kriter & & & $\leq 5$ & $\geq .90$ & $\geq .90$ & $\geq .90$ & $\leq .08$ & $\leq .08$ \\
\hline Model & 116.21 & 99 & 1.173 & 0.901 & 0.985 & 0.936 & 0.0427 & 0.049 \\
\hline
\end{tabular}

Modelin de uyum iyiliği kriterlerini sağlamakta olduğu bulgusuna ulaşılmıştır. Analiz sonuçları ise Tablo 9'da verilmiştir.

Tablo 9. Model Analiz Sonuçları

\begin{tabular}{|l|l|l|r|r|r|r|}
\hline \multicolumn{3}{|c|}{ Analiz Yolu } & $\boldsymbol{\beta}$ & S.H. & C.R. & P \\
\hline $\begin{array}{l}\text { Hedonik } \\
\text { Değer }\end{array}$ & $<---$ & Tüketici Yenilikçiliği & 0.557 & 0.185 & 4.448 & $* * *$ \\
\hline $\begin{array}{l}\text { Faydaci } \\
\text { Değer }\end{array}$ & $<---$ & Tüketici Yenilikçiliği & 0.676 & 0.183 & 5.111 & $* * *$ \\
\hline $\begin{array}{l}\text { Kullanıma } \\
\text { Devam Niyeti }\end{array}$ & $<---$ & Tüketici Yenilikçiliği & -0.126 & 0.117 & -1.412 & 0.158 \\
\hline
\end{tabular}




\begin{tabular}{|l|l|l|r|r|r|r|}
$\begin{array}{l}\text { Kullanıma } \\
\text { Devam Niyeti }\end{array}$ & <-- & Hedonik Değer & 0.703 & 0.075 & 8.288 & $* * *$ \\
\hline $\begin{array}{l}\text { Kullanıma } \\
\text { Devam Niyeti }\end{array}$ & $<---$ & Faydacı Değer & 0.489 & 0.096 & 4.79 & $* * *$ \\
\hline
\end{tabular}

Yapısal eşitlik modelinin analizi neticesinde tüketici yenilikçiliğinin hedonik ve faydacı değeri pozitif yönde anlamlı olarak etkilediği tespit edilmiştir. Hedonik ve faydacı değerin de akıllı saat kullanımına devam etme niyetini pozitif yönde anlamlı olarak etkilediği bulgusuna ulaşılmıştır. Tüketici yenilikçiliğinin ise kullanıma devam etme niyeti üzerinde anlamlı bir etkisine ulaşılamamıştır. Analiz neticesinde H2, H3, H4 ve H5 hipotezleri desteklenirken H1 hipotezi desteklenememiştir.

Ayrıca modelin uyumunu değerlendirmek için regresyon katsayılarının anlamlılığına bakılmıştır. Model için anlamlılık düzeyinin (p) tamamının 0.05 'ten küçük olduğu tespit edilmiştir. Bu sonuca göre gözlenen değişkenler ile gizli değişkenlerin iyi tahmin edildiği söylenebilmektedir. Aynı zamanda tüm maddelerin kritik oran değerlerine bakıldığında 0.50 'den büyük olduğu bulgusuna ulaşılmıştır. Kritik oran ve anlamlılık sonuçlarına göre regresyon katsayılarının anlamlı olduğu sonucuna ulaşılmıştır.

Yapısal eşitlik modelinin analizinden sonra hedonik ve faydacı değerin aracılık rolü Hayes (2018) tarafından geliştirilen Process Makro yöntemi ile yapılmıştır. Analizler Model 4 seçilerek yapılmıştır. Hedonik değerin aracılık testine ilişkin bulgular Tablo 10'da verilmiştir.

Tablo 10. Hedonik Değer Aracılık Testi

\begin{tabular}{|c|c|c|c|c|c|c|}
\hline \multicolumn{7}{|c|}{ Sonuç Değişkenleri } \\
\hline & & \multicolumn{2}{|c|}{ M (Hedonik Değer) } & & \multicolumn{2}{|c|}{ Y (Kullanıma Devam) } \\
\hline $\begin{array}{l}\text { Tahmin } \\
\text { Değiskenleri }\end{array}$ & & $\beta$ & S.H. & & $\beta$ & S.H. \\
\hline $\begin{array}{l}\text { X (Tüketici } \\
\text { Yenilikçiliği) }\end{array}$ & $\mathrm{a}$ & $.4446^{* * *}$ & .1033 & $c^{\prime}$ & .0572 & .0636 \\
\hline $\begin{array}{l}\text { M (Hedonik } \\
\text { Değer) }\end{array}$ & - & - & - & $\mathrm{b}$ & $.7983^{* * * *}$ & .0523 \\
\hline \multirow[t]{3}{*}{ Sabit Terim } & & $2.2686^{* * *}$ & .3152 & & $.6820^{* * * *}$ & .2160 \\
\hline & & \multicolumn{2}{|c|}{$\mathrm{R}^{2}=.1338$} & & \multicolumn{2}{|c|}{$\mathrm{R}^{2}=.7030$} \\
\hline & & $8.533 ; \mathrm{p}<.00$ & & & $19)=140.83$ & \\
\hline
\end{tabular}

Analiz sonucunda elde edilen bulgulara göre tüketici yenilikçiliğinin hedonik değeri (a yolu) pozitif yönde anlamlı olarak etkilemektedir. ( $\beta$ :.0.4446 \%95 CI [.2401, .6491], t:4.3050, $\mathrm{p}<.001$ ). Belirlilik katsayısı değeri de hedonik değerin \%13.38'inin tüketici yenilikçiliği tarafından açıklandığını göstermektedir. Hedonik değerin kullanıma devam etme niyetini (b yolu) anlamlı olarak etkilediği tespit edilmiştir. ( $\beta: .0 .7983 \% 95$ CI [.6947, .9018], t:15.2683, $\mathrm{p}<.001)$. Tüketici yenilikçiliğinin ise kullanıma devam etme niyetini anlamlı olarak etkilemediği tespit edilmiştir ( $\beta: .0 .0572 \% 95$ CI [-.0686, .1831], t:.9004, p>.001). Bulunan belirlilik katsayısı değeri de kullanıma devam etme niyetinin \%70.30'unun tüketici yenilikçiliği ve hedonik değer tarafından açıklandığını göstermektedir. Aracı değişken hedonik değerin olmadığı durumda ise tüketici yenilikçiliğinin kullanıma devam etme niyeti üzerindeki etkisi (c yolu) yani toplam etkiler de anlamlı olarak bulunmuştur. ( $\beta: .4121, \% 95$ CI [.2115, .6128], t: $4.0676, \mathrm{p}<.001)$. Toplam etkiler anlamlı olarak bulunduğu toplam etkiler güven aralığı alt ve üst değerlerinin sıfır değerini kapsamamış olmasından anlaşılmaktadır. Aracı değişken hedonik değerin de modele dahil edilmesi durumunda hesaplanan dolaylı etkiler anlamlı olarak 
bulunmuştur. ( $\beta: .3549, \% 95$ BCA CI [.1809, .5403]. Çünkü dolaylı etkiler güven aralığı alt ve üst değerleri sıfır değerini kapsamamaktadır. Etki büyüklüğü ise $\left(\mathrm{K}^{2}\right) 0.2998$ olarak elde edilmiştir. Bu değer 0.25 'e yakın olduğundan dolayı yüksek etki olduğu sonucuna varılmıştır. $\mathrm{Bu}$ nedenle hedonik değerin yüksek aracılık etkisi bulunmaktadır. Analiz neticesinde H6 hipotezi desteklenmiştir.

Faydacı değerin aracılık testi bulguları Tablo 11'de verilmiştir.

Tablo 11. Faydacı Değer Aracılık Testi

\begin{tabular}{|l|c|c|c|c|c|c|}
\hline \multicolumn{2}{|l|}{ Sonuç Değişkenleri } & \multicolumn{2}{|c|}{ M (Faydacı Değer) } & & Y (Kullanıma Devam) \\
\hline & & $\beta$ & S.H. & & $\beta$ & S.H. \\
\hline $\begin{array}{l}\text { Tahmin } \\
\text { Değişkenleri }\end{array}$ & $\mathrm{a}$ & $.4654^{* * *}$ & .0917 & $\mathrm{c}^{\prime}$ & .0214 & .0729 \\
\hline $\begin{array}{l}\text { X (Tüketici } \\
\text { Yenilikçiliği) }\end{array}$ & - & - & - & $\mathrm{b}$ & $.8396^{* * *}$ & .0659 \\
\hline $\begin{array}{l}\text { M (Faydacı } \\
\text { Değer) }\end{array}$ & & $2.2028^{* * *}$ & .2798 & & $.6435^{* * *}$ & .2486 \\
\hline Sabit Terim & & \multicolumn{2}{|c|}{$\mathrm{R}^{2}=.1768$} & \multicolumn{2}{|c|}{$\mathrm{R}^{2}=.6284$} \\
\hline & \multicolumn{2}{|l|}{$\mathrm{F}(1 ; 120)=25.764 ; \mathrm{p}<.001$} & & \multicolumn{2}{c|}{$\mathrm{F}(2 ; 119)=100.630 ; \mathrm{P}<.001$} \\
\hline
\end{tabular}

Analiz sonucunda elde edilen bulgulara göre tüketici yenilikçiliğinin faydacı değeri (a yolu) pozitif yönde anlamlı olarak etkilemektedir. ( $\beta: .0 .4654 \% 95$ CI [.2839, .6469], t:5.0758, $\mathrm{p}<.001)$. Belirlilik katsayısı değeri de faydacı değerin \%17.68'inin tüketici yenilikçiliği tarafından açıklandığını göstermektedir. Faydacı değerin kullanıma devam etme niyetini (b yolu) anlamlı olarak etkilediği tespit edilmiştir. ( $\beta$ :.0.8396 \%95 CI [.7092, .9700], t:12.7457, $\mathrm{p}<.001)$. Tüketici yenilikçiliğinin ise kullanıma devam etme niyetini anlamlı olarak etkilemediği tespit edilmiştir ( $\beta: .0 .0214 \% 95$ CI [-.1230, .1658], t:.2936, p>.001). Bulunan belirlilik katsayısı değeri de kullanıma devam etme niyetinin \%62.84'ünün tüketici yenilikçiliği ve faydacı değer tarafından açıklandığını göstermektedir. Aracı değişken faydacı değerin olmadığı durumda ise tüketici yenilikçiliğinin kullanıma devam etme niyeti üzerindeki etkisi (c yolu) yani toplam etkiler de bir önceki analiz sonuçlarında da belirtildiği üzere anlamlı olarak bulunmuştur. ( $\beta: .4121, \% 95$ CI $[.2115, .6128]$, t: 4.0676, p<.001). Aracı değişken faydacı değerin de modele dahil edilmesi durumunda hesaplanan dolaylı etkiler anlamlı olarak bulunmuştur. ( $\beta: .3907, \% 95$ BCA CI $[.0734, .2454]$. Çünkü dolaylı etkiler güven aralığı alt ve üst değerleri sıfır değerini kapsamamaktadır. Etki büyüklüğü ise $\left(\mathrm{K}^{2}\right) 0.3300$ olarak elde edilmiştir. Bu değer 0.25 'e yakın olduğundan dolayı yüksek etki olduğu sonucuna varılmıştır. $\mathrm{Bu}$ nedenle faydacı değerin yüksek aracılık etkisi bulunmaktadır. Analiz neticesinde H7 hipotezi desteklenmiştir.

\section{SONUÇ VE ÖNERILER}

Tüketici yenilikçiliği, belirli bir ürün kategorisindeki yeni ürünleri, pazarda gördükten hemen sonra diğer birçok tüketiciden nispeten daha erken satın alma eğiliminde olan yenilikçi tüketici davranış1 olarak ifade edilmektedir (Vandecasteele ve Geuens, 2010: 309). Son derece yenilikçi bireyler çeşitliliği tercih ederler ve yeni şeyleri kabul etme eğilimindedirler. Sürekli bilgi aramak yenilikçi tüketicilerin yenilik talepleriyle tutarlı olan daha fazla yeni bilgiye erişilmesini sağlar. $\mathrm{Bu}$ nedenle, düşük yenilikçilik seviyelerine sahip tüketicilerle karşılaştırıldığında, yüksek düzeyde yenilikçiliğe sahip olanların, algılanan işlevsel risk nedeniyle bilgi aramasını azaltma olasılığ 1 daha düşük olacaktır ve yüksek düzeyde satın alma 
istekliliğine sahip olacaktır (Zhang ve Hou, 2017: 245). Tüketici yenilikçiliğinin yakından ilişkili olduğu teknoloji pazarında her geçen gün gelişen mobil cihazlardan yeni bir cihaz türü olan akıllı saat popülerlik kazanmaya başlamıştır. Mobil cihaz endüstrisinde giyilebilir cihazlar ki özellikle akıllı saatler, günlük yaşamlarımız üzerinde önemli bir etkisi olacak şekilde geniş çapta kabul görmektedir. Akıllı saat, şekli biz insanların yüzyıllardır yakından kullandığı bir nesneye, yani kol saatine benzemesi açısından kolay kabul gören bir bilgi teknolojisi biçimidir (Choi ve Kim, 2016: 777). Giyilebilir bir cihaz olan akıllı saat, bir kullanıcının kişisel alanına yerleştirilebilen, vücuda takılabilen, taşınabilen elektronik bir bilgi işlem cihazıdır. Kullanıcının toplanan verileri farklı bir cihaza aktarılabilir ve analiz edilebilir. Bu cihazlar birçok kablosuz sensörle donatılmış olarak gelir ve vücutta kalp atış hızı, kandaki oksijen oranı ve uyku kalitesi gibi verileri analiz etme yeteneğine sahiptir (Anggraini, vd., 2019: 1267). Tüketicinin akıllı saat gibi ürünlerle ilgili alışveriş yaparken genellikle kabul gören iki tür tüketim değeri bulunmaktadır. Tüketici alışverişini rasyonel bir şekilde gerçekleştiriyorsa ve alışverişi bir görev olarak görüp amaca ulaşmayı planlıyorsa burada faydacı değerden söz edilmektedir. Fakat tüketici alışverişi amaçtan ziyade duygusal, eğlenceli bir faaliyet olarak görüp haz olma güdüsü ile hareket ediyorsa hedonik tüketim boyutu devreye girmektedir (Picot-Coupey vd., 2020: 2).

$\mathrm{Bu}$ açıklamalardan yola çıkarak çalışma tüketim değerleri olan hedonik ve faydacı değerlerin tüketici yenilikçiliği bağlamında akıllı saat kullanma düşüncesi üzerindeki etkilerini belirlemek amacıyla gerçekleştirilmiştir. Akıllı saatler giderek daha popüler hale gelmekte ve bu büyük pazar, işletmeler için büyük kâr potansiyeli sağlamaktadır. Akıllı saatler işlev bakımından zengin özelliklere sahip olduğu için, kullanıcılar bu cihazları kullanırken büyük zevk (hedonik değer) ve kullanışlılık (faydacı değer) elde edebilir ve bu durumda kullanma veya satın alma niyetlerinin sürekliliğini teşvik edecek en önemli nedenlerden biri olarak karşımıza çıkmaktadır. $\mathrm{Bu}$ akıllı teknoloji üzerinde yapılmış çalışmalar bulunsa da tüketicinin yenilikçiliği ve akıllı saat kullanma ya da kullanımına devam etme konusunda hala literatürde eksiklik bulunmaktadır. Bu gerçekleştirilen çalışma giyilebilir cihazların benimsenmesi açısından çıkarımlar bulundurmakla birlikte akıllı saat kullanımının tahmin edilmesi açısından bir girişimi temsil etmektedir. Buradan yola çıkarak çalışmadaki sonuçlar tüketici yenilikçiliğinin hedonik ve faydacı değerin akıllı saat kullanımına devam niyetinin sürekliliği üzerindeki etkisini açıklamak için de fayda sağlayacaktır.

Çalışmadan elde edilen sonuçlar güncel literatüre birtakım katkılar sağlamaktadır. İlk olarak sonuçlar tüketicilerin akıllı saatin faydacı yönünden memnun olduklarını fakat bu memnuniyetin hedonik yani zevk, eğlence ve haz yönünde daha yüksek olduğunu göstermektedir. $\mathrm{Bu}$ sonuçlar üreticilerin ve akıllı saat şirketlerinin, ürünün sağlık, fitness, iletişim gibi faydacı yönlerine ağırlık verirken aynı zamanda oyun, eğlence gibi hazcı yönlerini de geliştirmeye yönlenmeleri açısından kılavuzluk edecektir. Tüketici yenilikçiliği üzerine gerçekleştirilen çalışmalar bulunmakla birlikte bu çalışmadan elde edilen sonuçlar ile tüketici yenilikçiliğinin faydacı algılarına ve davranışsal olarak hazcı değerlerine etki ettiği de tespit edilmiştir. Bu nedenle hedonik ve faydacı değeri artırarak devam niyetini yüksek düzeye çıkarmak ve tüketicinin akıllı saat kullanımına devam etme niyetini daha da canlandırmanın bir adımı olabilir. Akıllı saatin henüz yeni yeni kullanılmaya başlanması ve tanıtılması açısından çalışmamız öncülük etmektedir. Ayrıca çalışma, literatüre her geçen gün gelişen teknolojinin bir ürünü olan akıllı saatin kullanılma niyeti ile ilgili bilgi vermesi açısından katkı sağlamıştır. Daha geniş kapsamlı giyilebilir teknoloji ürünleri üzerine de çalışmalar yapılarak literatüre yeni bilgilerin eklenilmesi önerilmektedir. 
$\mathrm{Bu}$ çalışmanın kısıtı veri toplama yöntemi olarak seçtiğimiz anket ifadeleri sınırlayıcı olabileceğinden diğer çalışmalarda sorular genişletilerek ve açık uçlu ifadelere yer vererek katılımcının görüsslerinden de fayda sağlanabilir. Akıllı saati kullanıma devam etme niyetinde hedonik ve faydacı değeri gözlemlememiz de bir sınır olabileceğinden, devam etme niyeti üzerinde etkisi olabileceği düşünülen farklı boyutlar da çalışmaya dâhil edilebilir. Ayrıca tüketici davranışını doğru bir şekilde tahmin etmek güçtür. Bu güçlüğü giderebilmek amacıyla daha geniş bir zaman dilimini kapsayacak şekilde çalışmalar gerçekleştirilebilir. Son olarak tüketicilerin akıllı saate yönelik tercihlerini ölçebilmek amacıyla akıllı saatlerin farklı özellikleri üzerinde durularak bunlara verilen değerler tespit edilmeye çalışılabilir.

Bu çalışma için Kastamonu Üniversitesi Sosyal ve Beşeri Bilimler Araştırma ve Yayın Etik Kurulu’nun 25.12.2020 tarih ve 4/11 sayılı kararınca “Etik Kurul Onayı” alınmıştır.

\section{KAYNAKÇA}

AL-EMRAN, M., GRANIĆ, A., AL-SHARAFI, M. A., AMEEN, N. \& SARRAB, M. (2020). "Examining The Roles Of Students' Beliefs And Security Concerns For Using Smartwatches in Higher Education", Journal of Enterprise Information Management.

AMORIM, M. M. R. P. D. (2017). "Hedonic And Utilitarian Attitudes Towards Technology And İnovation: Purchase Intentions Of Audio Devices: the AirPods Case" (Doctoral dissertation).

ANGGRAINI, N., KABURUAN, E. R., WANG, G. \& JAYADI, R. (2019). “Usability Study and Users' Perception of Smartwatch: Study on Indonesian Customer". Procedia Computer Science, 161: 1266-1274.

ASHRAF, R.U., HOU, F. \& AHMAD, W. (2019). "Understanding Continuance Intention to Use Social Media in China: The Roles of Personality Drivers, Hedonic Value, and Utilitarian Value". International Journal of Human-Computer Interaction, 35(13): 1216-1228.

ATULKAR, S. \& KESARI, B. (2017). "Satisfaction, Loyalty And Repatronage İntentions: Role Of Hedonic Shopping Values". Journal of Retailing and Consumer Services, 39: 23-34.

BÖLEN, M. C. (2020a). "Exploring The Determinants Of Users' Continuance Intention In Smartwatches". Technology in Society, 60: 101209.

BÖLEN, M. C. (2020b). "From Traditional Wristwatch To Smartwatch: Understanding The Relationship Between Innovation Attributes, Switching Costs And Consumers' Switching Intention”. Technology in Society, 63: 101439.

CHAE, J. M. (2009). "Consumer Acceptance Model of Smart Clothing According To Innovation". International Journal of Human Ecology, 10(1): 23-33.

CHAUHAN, V., YADAV, R. \& CHOUDHARY, V. (2019). “Analyzing The Impact Of Consumer Innovativeness And Perceived Risk In Internet Banking Adoption: A Study Of Indian Consumers”. International Journal of Bank Marketing, 37(1): 323-339. 
CHO, W. C., LEE, K. Y. \& YANG, S. B. (2019). "What Makes You Feel Attached To Smartwatches? The Stimulus-Organism-Response (S-O-R) Perspectives". Information Technology \& People, 32(2): 319-343.

CHOI, J. \& KIM, S. (2016). "Is The Smartwatch An IT Product Or A Fashion Product? A Study On Factors Affecting The İntention To Use Smartwatches". Computers in Human Behavior, 63: 777-786.

CHUNG, Y. S. (2015). "Hedonic And Utilitarian Shopping Values In Airport Shopping Behavior". Journal of Air Transport Management, 49: 28-34.

ÇAVUŞOĞLU, S., DEMIRAĞ, B. \& DURMAZ, Y. (2020). "Investigation Of The Effect Of Hedonic Shopping Value On Discounted Product Purchasing”. Review of International Business and Strategy.

FIRMANSYAH, I. (2016). “Consumer Innovativeness And New Product Adoption: The Case Of Payment Card”. Marketing \& Consumer Behaviour, Course code: MCB-80433.

GÜVEN E. (2018). “Tüketicilerin Tatmin ve Tutumlarının Belirlenmesinde Hedonik Ve Faydacı Değerlerin Rolü: Üniversite Öğrencilerinin Cep Telefonu Kullanımları Üzerine Bir Uygulama”. Dumlupınar Üniversitesi Sosyal Bilimler Dergisi, 55: 157-173.

HA, T., BEIJNON, B., KIM, S., LEE, S. \& KIM, J. H. (2017). "Examining User Perceptions Of Smartwatch Through Dynamic Topic Modeling". Telematics and Informatics, 34(7): 1262-1273.

HAYES, A. F. (2018). "Introduction to mediating, moderating and conditional process analysis: A refresion based approach (2. Bask1).” New York: The Guilford Press.

HONG, J. C., LIN, P. H. \& HSIEH, P. C. (2017). “The Effect Of Consumer Innovativeness On Perceived Value And Continuance Intention To Use Smartwatch". Computers in Human Behavior, 67: 264-272.

HWANG, J., PARK, S. \& KIM, I. (2020). "Understanding Motivated Consumer Innovativeness In The Context Of A Robotic Restaurant: The Moderating Role Of Product Knowledge”. Journal of Hospitality and Tourism Management, 44: 272-282.

JONES, M. A., REYNOLDS, K. E. \& ARNOLD, M. J. (2006). "Hedonic And Utilitarian Shopping Value: Investigating Differential Effects On Retail Outcomes”. Journal Of Business Research, 59(9): 974-981.

JU, N. \& LEE, K.Y. (2020). “Consumer Resistance To Innovation: Smart Clothing. Fashion and Textiles, 7(21): 1-19.

JUNG, Y., KIM, S. \& CHOI, B. (2016). “Consumer Valuation Of The Wearables: The Case of Smartwatches". Computers in Human Behavior, 63: 899-905.

KAUTISH, P. \& SHARMA, R. (2019). "Value Orientation, Green Attitude And Green Behavioral Intentions: An Empirical Investigation Among Young Consumers". Young Consumers, 20(4): 338-358. 
KESARI, B. \& ATULKAR, S. (2016). "Satisfaction Of Mall Shoppers: A Study On Perceived Utilitarian And Hedonic Shopping Values". Journal of Retailing and Consumer services, 31: 22-31.

KIM, J. J., CHOE, J. Y. J. \& HWANG, J. (2020). “Application Of Consumer Innovativeness To The Context Of Robotic Restaurants". International Journal of Contemporary Hospitality Management. DOI 10.1108/IJCHM-06-2020-0602.

KIM, Y. H. (2008). “An Empirical Examination Of Consumers' Innovation Adoption: The Role Of Innovativeness, Fashion Orientation, And Utilitarian And Hedonic Consumers' Attitudes" (Doctoral dissertation, University of North Carolina at Greensboro).

KÖROĞLU, A. \& YILDIZ, S. (2019). "Hedonik ve Faydacı Tüketimin Elektronik Pazarlama ve Satın Alma Davranışı Üzerine Etkisi. Gümüşhane Üniversitesi Sosyal Bilimler Enstitüsü Elektronik Dergisi, 10(EkSayı): 351-365.

KREY, N., CHUAH, S. H. W., RAMAYAH, T. \& RAUSCHNABEL, P. A. (2019). "How Functional And Emotional Ads Drive Smartwatch Adoption”. Internet Research, 29(3): 578-602.

KUIKKA, A. \& LAUKKANEN, T. (2012). "Brand Loyalty And The Role Of Hedonic Value". Journal of Product \& Brand Management, 21(7): 529-537.

LEE, S. \& KIM, D. Y. (2018). “The Effect Of Hedonic And Utilitarian Values On Satisfaction And Loyalty Of Airbnb Users". International Journal of Contemporary Hospitality Management, 30(3): 1332-1351.

LEE, C. H. \& WU, J. J. (2017). “Consumer Online Flow Experience”. Industrial Management \& Data Systems, 117(10): 2452-2467.

LEICHT, T., CHTOUROU, A. \& YOUSSEF, K.B. (2018). “Consumer Innovativeness And Intentioned Autonomous Car Adoption". Journal of High Technology Management Research, 29: 1-11.

LIN, Y., LUO, J., CAI, S., MA, S. \& RONG, K. (2016). "Exploring The Service Quality In The E-Commerce Context: A Triadic View". Industrial Management \& Data Systems, 116(3): 388-415.

MANI, Z. \& CHOUK, I. (2017). "Drivers Of Consumers' Resistance To Smart Products". Journal of Marketing Management, 33(1-2): 76-97,

MIDGLEY, D. F. \& DOWLING, G. R. (1978). "Innovativeness: The Concept And its Measurement". Journal of Consumer Research, 4: 229-242.

NASCIMENTO, B., OLIVEIRA, T. \& TAM, C. (2018). "Wearable Technology: What Explains Continuance Intention In Smartwatches?". Journal of Retailing and Consumer Services, 43: 157-169.

NIKOU, S. (2019). "Factors Driving The Adoption Of Smart Home Technology: An Empirical Assessment". Telematics and Informatics, 45: 101283. 
NOBLE, S. M., GRIFFITH, D. A. \& WEINBERGER, M. G. (2005). “Consumer Derived Utilitarian Value And Channel Utilization In A Multi-Channel Retail Context”. Journal of Business Research, 58(12): 1643-1651.

NOH, M., RUNYAN, R. \& MOSIER, J. (2014). "Young Consumers' Innovativeness And Hedonic/Utilitarian Cool Attitudes". International Journal of Retail \& Distribution Management, 42(4): 267-280.

OVERBY, J. W. \& LEE, E. J. (2006). "The Effects Of Utilitarian And Hedonic Online Shopping Value On Consumer Preference And Intentions". Journal of Business Research, 59(10-11): 1160-1166.

OZTÜRK, A. B., NUSAIR, K., OKUMUŞ, F. \& HUA, N. (2016). “The Role Of Utilitarian And Hedonic Values On Users' Continued Usage Intention In A Mobile Hotel Booking Environment". International Journal of Hospitality Management, 57: 106-115.

PERlMAN, D., SAMOST, A., DOMEL, A. G., MEHLER, B., DOBRES, J. \& REIMER, B. (2019). "The Relative Impact Of Smartwatch And Smartphone Use While Driving On Workload, Attention, And Driving Performance”. Applied Ergonomics, 75: 8-16.

PERSAUD, A. \& SCHILlO, S. R. (2017). "Purchasing Organic Products: Role Of Social Context And Consumer İnnovativeness". Marketing Intelligence \& Planning, 35: 130146.

PICOT-COUPEY, K., KREY, N., HURÉ, E. \& ACKERMANN, C. L. (2020). "Still Work And/Or Fun? Corroboration Of The Hedonic And Utilitarian Shopping Value Scale". Journal of Business Research.

RAŠKOVİ́, M., DING, Z., ŠKARE, V., DOŠEN, Đ. O. \& ŽABKAR, V. (2016). “Comparing Consumer Innovativeness And Ethnocentrism Of Young-Adult Consumers". Journal of Business Research, 69(9): 3682-3686.

RYU, K., HAN, H. \& JANG, S. S. (2010). "Relationships Among Hedonic And Utilitarian Values, Satisfaction And Behavioral Intentions In The Fast-Casual Restaurant İndustry". International Journal of Contemporary Hospitality Management, 22(3): 416432.

TRUONG, Y., KLINK, R. R., SIMMONS, G., GRINSTEIN, A. \& PALMER, M. (2017). "Branding Strategies For High-Technology Products: The Effects Of Consumer And Product Innovativeness". Journal of Business Research, 70: 85-91.

TÜRK DİL KURUMU. (2020). “Yenilikçi Nedir?”, https://sozluk.gov.tr/, 15.01.2020.

VANDECASTEELE, B. \& GEUENS, M. (2010). "Motivated Consumer Innovativeness: Concept, Measurement, And Validation". International Journal of Research in Marketing, 27(4): 308-318.

VIEIRA, V., SANTINI, F. O. \& ARAUJO, C. F. (2018). “A Meta-Analytic Review Of Hedonic And Utilitarian Shopping Values”. Journal of Consumer Marketing, 35(4): 426-437.

WU, L. H., WU, L. C. \& CHANG, S. C. (2016). "Exploring Consumers' Intention To Accept Smartwatch". Computers in Human Behavior, 64: 383-392. 
XIE, Y. H. (2008). "Consumer Innovativeness and Consumer Acceptance of Brand Extensions". Journal of Product \& Brand Management, 17(4): 235-243.

YANG, Z., JUN, M. \& PETERSON, R.T. (2004). "Measuring Customer Perceived Online Service Quality: Scale Development And Managerial Implications". International Journal of Operations \& Production Management, 24 (11): 1149-1174.

ZHANG, Z. \& HOU, Y. (2017). "The Effect Of Perceived Risk On Information Search For Innovative Products And Services: The Moderating Role Of Innate Consumer Innovativeness". Journal of Consumer Marketing, 34(3): 241-254.

ZHANG, F., SUN, S., LIU, C. \& CHANG, V. (2020). “Consumer Innovativeness, Product Innovation And Smart Toys". Electronic Commerce Research and Applications, 41: 113.

ZHENG, X., MEN, J., YANG, F. \& GONG, X. (2019). "Understanding Impulse Buying In Mobile Commerce: An Investigation Into Hedonic And Utilitarian Browsing". International Journal of Information Management, 48: 151-160. 